\title{
Developing a DEM and Elucidating through SWAT to Conserve Soil in Kulfo Watershed of Rift Valley Basin, Ethiopia
}

\author{
Melkamu Teshome Ayana ${ }^{(D,}{ }^{1}$ Yechale Kebede Bizuneh, ${ }^{2}$ Abera Ermias Koshuma, \\ Aschalew Cherie Workneh, ${ }^{1}$ Belete Meketew Ali, ${ }^{1}$ and Tarun Kumar Lohani ${ }^{1}$ \\ ${ }^{1}$ Water Technology Institute, Arba Minch University, P.O. Box 21, Arba Minch, Ethiopia \\ ${ }^{2}$ College of Social Science and Humanity, Arba Minch University, P.O. Box 21, Arba Minch, Ethiopia
}

Correspondence should be addressed to Melkamu Teshome Ayana; melkamu.teshome@amu.edu.et

Received 29 September 2021; Accepted 18 January 2022; Published 21 February 2022

Academic Editor: Teodoro M. Miano

Copyright (c) 2022 Melkamu Teshome Ayana et al. This is an open access article distributed under the Creative Commons Attribution License, which permits unrestricted use, distribution, and reproduction in any medium, provided the original work is properly cited.

\begin{abstract}
Due to uninterrupted erosion and transportation, huge volume of sediments carried away by streams and rivers are finally deposited on the meanders, lakes, and reservoirs when the velocity of the surface water flow decreases. Kulfo River in the southern part of Ethiopia faces a challenge due to massive deposit of sediments. Hydrometeorological and spatial data of Kulfo watershed from the observed stream flow data series near Kulfo bridge and four meteorological station data were used to assess the depositional environment of Kulfo watershed. The data length covers the period from 2000 to 2019. Geomorphic parameters of the watershed were developed by using a $30 \mathrm{~m} \times 30 \mathrm{~m}$ digital elevation model (DEM). The spatial distribution of sediment yield of the study area was estimated using SWAT, the soil and water assessment tool. Scenarios were developed to assess the effectiveness of watershed management interventions provided at the watershed and critical subwatershed level. The model genuinely replicated the observed discharge and sediment with an overall performance of 0.75 as measured by NSE. Twenty-one subbasins were created, and the observed average sediment yield was calculated as 11.9 ton/ha/y. The observed average sediment yield reduction at the hotspot subwatershed level postapplication of contouring, filter strip, terracing, and strip cropping were $40.79 \%$, 57.94\%, $66.02 \%$, and $62.93 \%$, respectively. By intricately analyzing, it can be referred that terracing is the best conservation measure to be incorporated into the affected subbasins.
\end{abstract}

\section{Introduction}

Loss of soil is a natural geological denudation practice of detachment of upper soil by natural agencies like water, wind, glacier, and tidal effects though some anthropogenic interference cannot be ruled out. It reduces the fertility of land and eases the productivity of agricultural land $[1,2],[3]$. Sediment accumulation for several years reduces the capacity of reservoirs [4-6], whereas continuous siltation puts an adverse effect on the quality of the water in the reservoirs since they play an imperative role by the contaminants to sink [7]. Soil erosion has become a matter of concern across the world especially, in mountainous areas with steep slopes where the topsoil is blanketed by extensive weathered soil. Gigantic growth of population, both human and animal, and injudicious use of natural resources for many years are the primary reasons for most of the land degradation in countries [6, 8-10]. Massive deforestation for the sake of increasing cultivable and grazing lands including burning of forests to produce charcoal has hindered the stability of natural resources rather than increasing productivity per unit area. On the contrary, soil erosion may be the root cause of large-scale sediment deposits though a sizeable number of populations relying their livelihoods directly from the soil. Due to reduction in production from agricultural land, people were forced to change the farming land from one to the other. Over grazing and indecorously managed land use/ land cover (LULC) may also contribute to soil loss, changing the existence of the basins in large extent. This hampers in aggravating the climate change augmenting soil degradation 
in the subbasin to a wide extent. In spite of several measures undertaken by different organizations, high rate of soil erosion is still prevailing. Land degradation is directly or indirectly associated to soil erosion comprising of nearly $85 \%$, causing decline in crop productivity (17\%) [10]. As per the Global Assessment of Soil Degradation (GLASOD), 65\% of soils on agricultural lands in Africa have degraded (31\% of permanent agricultural lands and $19 \%$ of forests and jungles) [11-13] since mid of twentieth century. The problem is specifically a threat to the Ethiopia escalating year after year. Loss of soil organic matter, soil erosion, and soil nutrient reduction were also reported as the most critical components of the soils and associated with ecosystem functions in Ethiopia [14]. Many natural and artificial reservoirs have lost their original capacity which hinders the growth and development of the countries in various ways [5]. Ethiopia is gifted with potential irrigable land which exceeds 3.8 million ha [15]. $80 \%$ or more Ethiopian people depend on rain-fed agriculture, and survival is solely linked to the preparation of agricultural land, no matter how the population is dense or sparse at the highland or lowland areas. Most of the local farmers use traditional farming which accelerates top soil and important nutrients are removed and in due course of time become nonproductive. In order to compensate, massive agricultural land expansion has been taking place and soil erosion becomes a major challenge and causes reduction of irrigable lands. Many irrigation, hydropower, and water supply reservoirs have lost their designed capacity impeding the country's development. Soil erosion in Ethiopia causes approximately one billion USD per annum decelerating the economic development $[16,17]$. Soil erosion is common in both the highland and lowland areas of Ethiopia, but the highland areas are highly susceptible, and it has been reported that an estimated amount of $1.5 \times 10^{4} \mathrm{~kg}$ of soil is eroded only from the highlands of Ethiopia per year [17-19], even if the watersheds in the northern part of Ethiopia intimidates a loss of tons of soil per hectare per annum. Most of the findings indicated total soil loss of more than $35 \%$ due to the severity of erosion in the catchments $[16,20,21]$. Hurni et al. [22] quantified that soil loss in Ethiopia totals to approximately 42 ton/ha/y and depicted as mainly caused due to erosion of cultivated lands. In the southern and lowlands of the Ethiopia, there are very few information available since deep study has not yet been done in those areas due to shrubs, forests, and inaccessibility.

To identify hotspot areas of soil loss and support with different conservation planning measures, soil erosion modeling tools such as revised universal soil loss equation (RUSLE), universal soil loss equation (USLE), soil and water assessment tools (SWAT), APEX, and MIKE SHE 11 are commonly and extensively utilized $[17,23,24]$. In recent years, the geographic information system (GIS) has been commonly used to assess the erosion of soil and develop models at the catchment level for sediment deposits. Using those models, estimating the soil loss from the watersheds identifying the hotspot regions is important in order to preserve naturally balanced watershed, and hence, the Kulfo watershed management study is also vital to reduce soil erosion at the watershed level which can be caused by several anthropogenic and natural activities. In order to assess the spatiotemporal distribution of yield of sediments in Kulfo watershed using the SWAT model, further recommendations for proper watershed management practices have been initiated.

\section{Methods and Materials}

2.1. Study Area and Data Availability. Kulfo watershed is sited at the central part of Ethiopian rift valley lakes basin, between $37^{\circ} 18^{\circ} \mathrm{E}-37^{\circ} 38^{\prime} \mathrm{E}$ longitudes and $5^{\circ} 55^{\prime} \mathrm{N}-6^{\circ} 16^{\prime} \mathrm{N}$ latitudes. Kulfo River is one of the dominant rivers in the Abaya-Chamo subbasin system. It originates from Guge mountains, flowing towards east into Lake Chamo. The river flow of Kulfo watershed is gauged at Kulfo near the bridge. The long term (1995-2012) mean annual flow is $11.74 \mathrm{~m}^{3} / \mathrm{s}$ with an annual capacity of 372.07 million cubic meters. It attains its peak flow in April and October. The yearlong rainfall varies from $750 \mathrm{~mm}$ in the dry lowlands near Arba Minch to $3342 \mathrm{~mm}$ in the mountainous regions of Gerese, with average annual rainfall of $1049 \mathrm{~mm}$. The annual mean temperature fluctuates in between $23.05^{\circ} \mathrm{C}$ and $25.87^{\circ} \mathrm{C}$. The total drainage area covers $367 \mathrm{~km}^{2}$ with an average slope of $16 \%$ and dominantly covered with Orthic Acrisols soil type and agricultural land. The elevation of the catchment ranges from $1235 \mathrm{~m}$ to $3547 \mathrm{~m}$ above the mean sea level ( $\mathrm{m} \mathrm{s}$ 1.). The geographic location of the selected study area is shown in Figure 1.

The observed streamflow data series near the bridge of Kulfo and four meteorological stations data in and around the watershed with different spatial and temporal length were collected from Ministry of Water, Irrigation, and Electricity (MoWIE) and National Meteorological Agency (NMA). MoWIE and NMA are governmental organizations responsible for the collection, analysis, and dissemination of stream flow and climate data in Ethiopian basins, respectively. The available stream flow and meteorological data covers a period from 2000 to 2019 (Table 1).

2.1.1. SWAT Model Setup and Model Inputs. Land cover and soil of the catchment were subdivided into basins and subbasins using SWAT analysis and further delineated into hydrologic response units (HRUs). A number of dissimilar physical processes to be generated in a basin were agreed upon. The model involves a number of spatial and time series input data for simulation of the watershed [25]. Major input datasets include topography (DEM, slope, and slope shape), soil, and land use/land cover; whereas, time series includes climatic and hydrological data (flow and sediment). A $30 \mathrm{~m} \times 30 \mathrm{~m}$ resolution DEM of Kulfo watershed was obtained from Internet sources. Predefined watersheds and stream datasets were contemplated to simulate watershed alignment during the watershed delineation process. Overland and channel slope, channel length of main, and tributary streams are the geomorphic parameters generated by the DEM during the study.

2.2. Calibration and Validation. The replication capability of the model was evaluated in terms of visual inspection of 


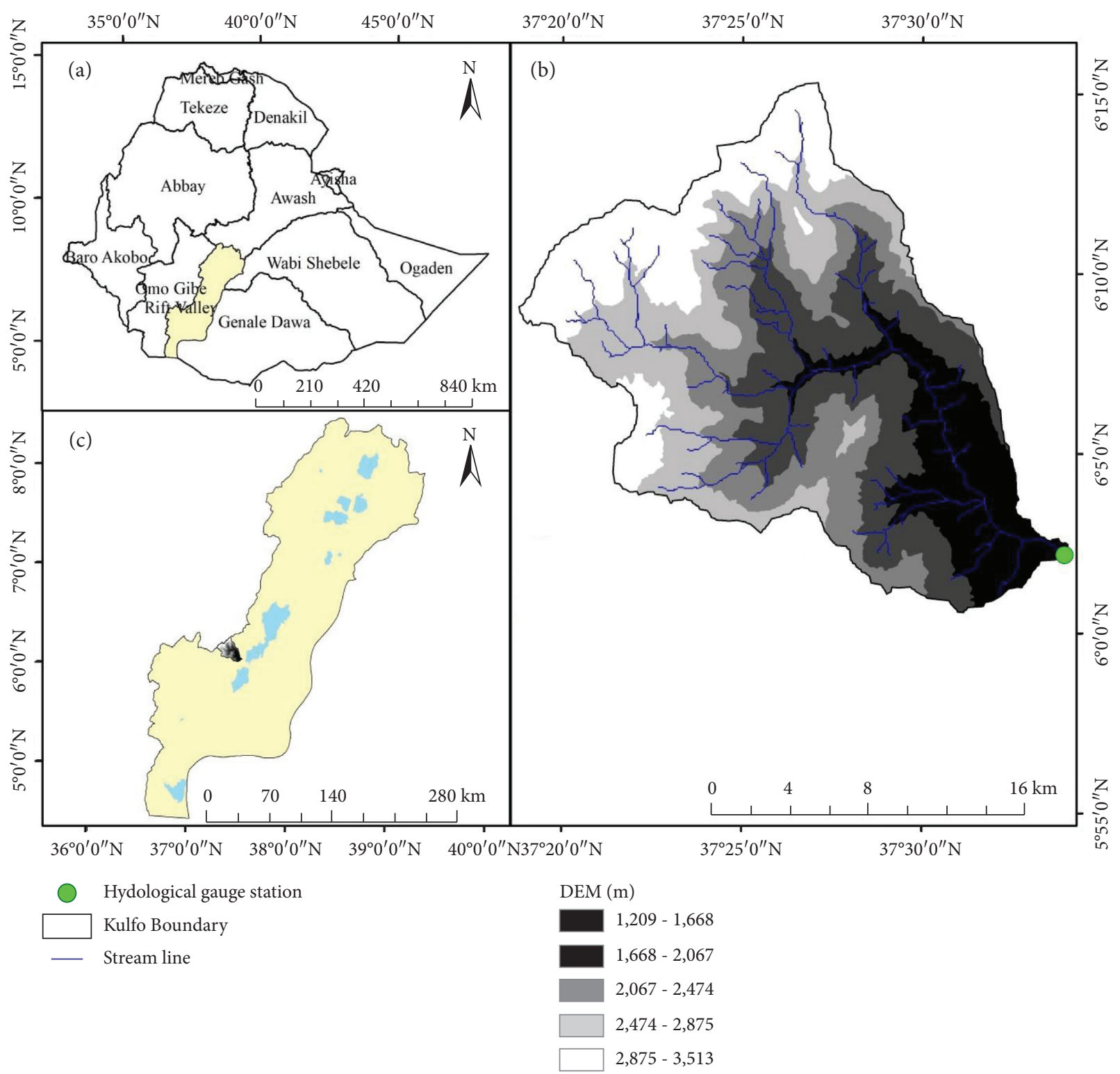

Figure 1: Study area: (a) major Ethiopian basins, (b) Kulfo watershed with its drainage lines, and (c) rift valley basin and lakes.

TABLE 1: Data length and locations of meteorological stations used.

\begin{tabular}{lccccccc}
\hline S. no. & Station name & Latitude & Longitude & Class & Rainfall & $T_{\max }$ & $T_{\min }$ \\
\hline 1 & Gerese & 5.6 & 37.2 & 2 & Yes & Yes & Yes \\
2 & Arba Minch & 6.1 & 37.4 & 1 & Yes & Yes \\
3 & Deramalo & 6.32 & 37.3 & 4 & Yes & Yes & Yes \\
4 & Chencha & 6.22 & 38 & 4 & Yes & Yes & Yes \\
\hline
\end{tabular}

$T_{\max }$, maximum temperature; $T_{\min }$, minimum temperature.

simulated and observed sediment plot. Graphical comparison, three efficiency measuring techniques such as relative volume error (RVE), coefficient of determination $\left(R^{2}\right)$, and Nash-Sutcliffe efficiency (NSE) were utilized for model performance evaluation. The detailed description of the performance indicators used is given in various documents [26], [27].
2.3. Developing Watershed Management Scenarios. Various structural and nonstructural soil erosion reduction processes are applied to identify the hotspot regions in the SWAT model. These include filter strips, grassed waterways, contouring, terracing, tile drains, strip cropping, fire, plant parameter update, residue management, and generic conservation practices. In order to make the study more 
TABLE 2: Performance results of the model during calibration and validation of sediment simulation.

\begin{tabular}{|c|c|c|c|c|c|}
\hline \multirow{2}{*}{ Simulation (year) } & \multicolumn{2}{|c|}{ Uncertainty measures } & \multicolumn{3}{|c|}{ Model performance indicator } \\
\hline & P-factor & R-factor & $R^{2}$ & NSE & RVE \\
\hline Calibration (1995-2006) & 0.72 & 0.63 & 0.77 & 0.79 & -6.24 \\
\hline Validation (2007-2012) & 0.64 & 0.68 & 0.83 & 0.7 & -18 \\
\hline
\end{tabular}

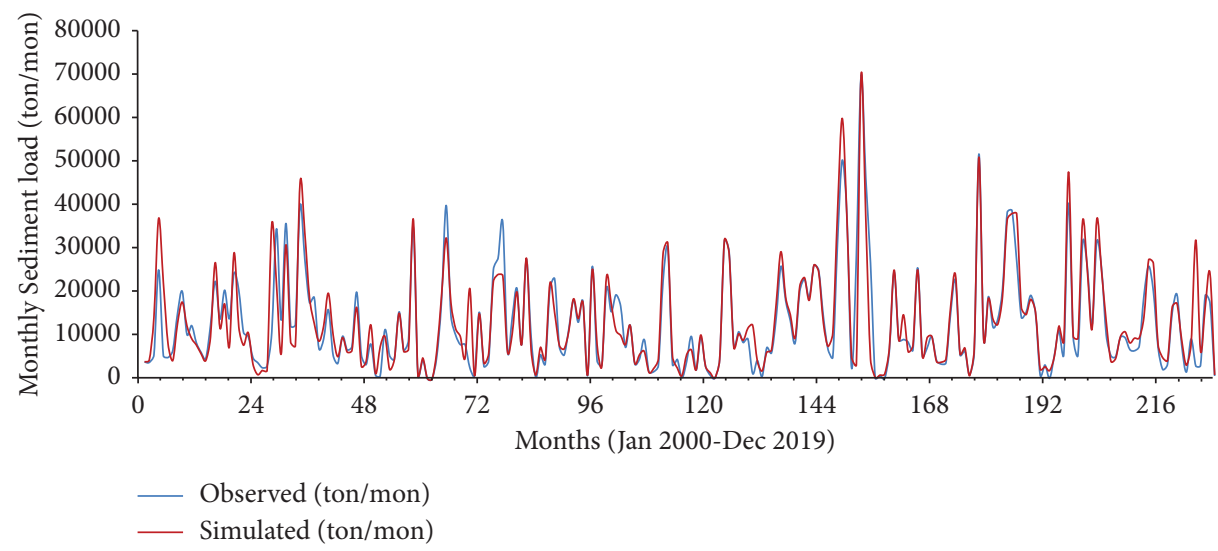

Figure 2: Calibration and validation of monthly sediment load.

economic, depending on the experiences shared by the local community and topography of the catchment, filter strips, contouring, terracing, and strip cropping were selected.

\section{Results and Discussion}

3.1. Model Calibration Results and Validation of Sediment Flow. The same datasets for streamflow were used for calibration as well as validation. Sediment flow data for two set of years were collected from MoWIE. The performance of the model resulted with NSE of $79 \%$ and $70 \%$ during calibration and validation respectively was noted and the results obtained during streamflow simulation were presented in Table 2.

The plot of hydrograph of simulated sediment flow against the observed sediment produces an excellent result (Figure 2).

\subsection{Sediment Yield and Kulfo Watershed Sediment Reduction.} To get the spatial distribution of average sediment yield annually at the subbasin level, the SWAT model was run by using twenty-four years (2000-2019) hydrometeorological data. The spatial distribution of sediment yield of Kulfo watershed was acknowledged from the simulated annual sediment yield, and the result shows that they lie in between $3.38 \mathrm{ton} / \mathrm{ha} / \mathrm{y}$ and $38.55 \mathrm{ton} / \mathrm{ha} / \mathrm{y}$ with an annual mean of 11.9 ton/ha/y for the subbasins (Table 3 ).

Spatial distribution of sediment yield from Kulfo watershed was projected from the simulated sediment outputs for each of the subbasins. The soil erosion levels in the basin were classified as very high (>20 t/ha/y), high (15-20 t/ha/y), moderate $(10-15 \mathrm{t} / \mathrm{ha} / \mathrm{y})$, low $(5-10 \mathrm{t} / \mathrm{ha} / \mathrm{y})$, and very low $(0-5 \mathrm{t} / \mathrm{ha} / \mathrm{y})$. As per the information gathered from local farmers supported by the field visit, subbasins 8 and 14 are
TABLE 3: Average yearly yield of sediment for hotspot subbasins of Kulfo watershed.

\begin{tabular}{lc}
\hline Subbasins & Average sediment yield $\left(\right.$ tons $\left.\mathrm{ha}^{-1} \mathrm{y}^{-1}\right)$ \\
\hline 1 & 10.86 \\
2 & 31.44 \\
3 & 6.59 \\
4 & 38.55 \\
5 & 4.02 \\
6 & 27.34 \\
7 & 6.03 \\
8 & 8.25 \\
9 & 29.98 \\
10 & 5.8 \\
11 & 10.73 \\
12 & 15.09 \\
13 & 6.62 \\
14 & 9.45 \\
15 & 5.69 \\
16 & 5.69 \\
17 & 7.56 \\
18 & 4.78 \\
19 & 6.65 \\
20 & 5.67 \\
21 & 3.38 \\
\hline
\end{tabular}

classified as low, and hence, these two subbasins were given due consideration for detailed analysis. The sediment contributing regions mapped by using the SWAT model are shown in Figure 3.

3.2.1. Sediment Yield Reduction Scenarios. Once the critical source areas of sediment yield were identified, it became promising to develop a sediment yield reduction method for those high sediments producing subbasins. On the basis of 


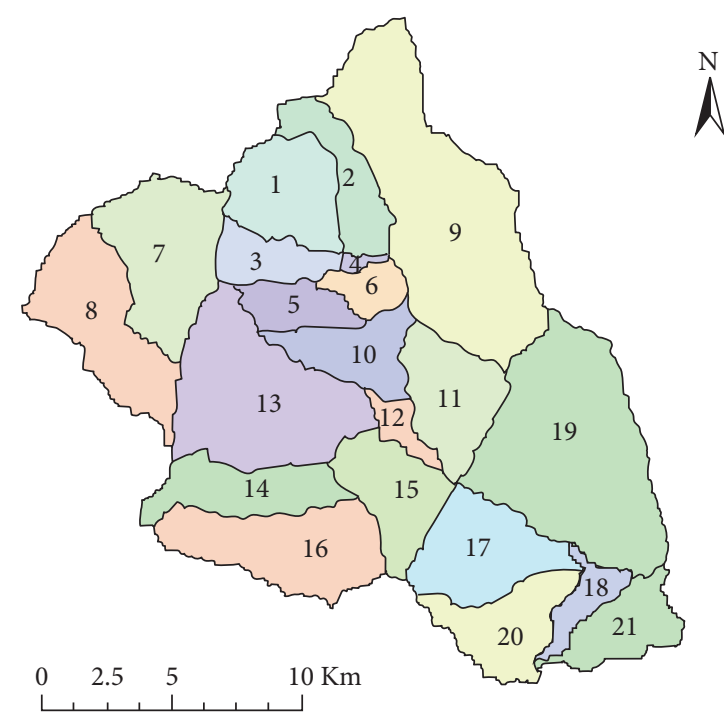

FIGURE 3: Spatial distribution of Kulfo subwatersheds and its sediment yield.

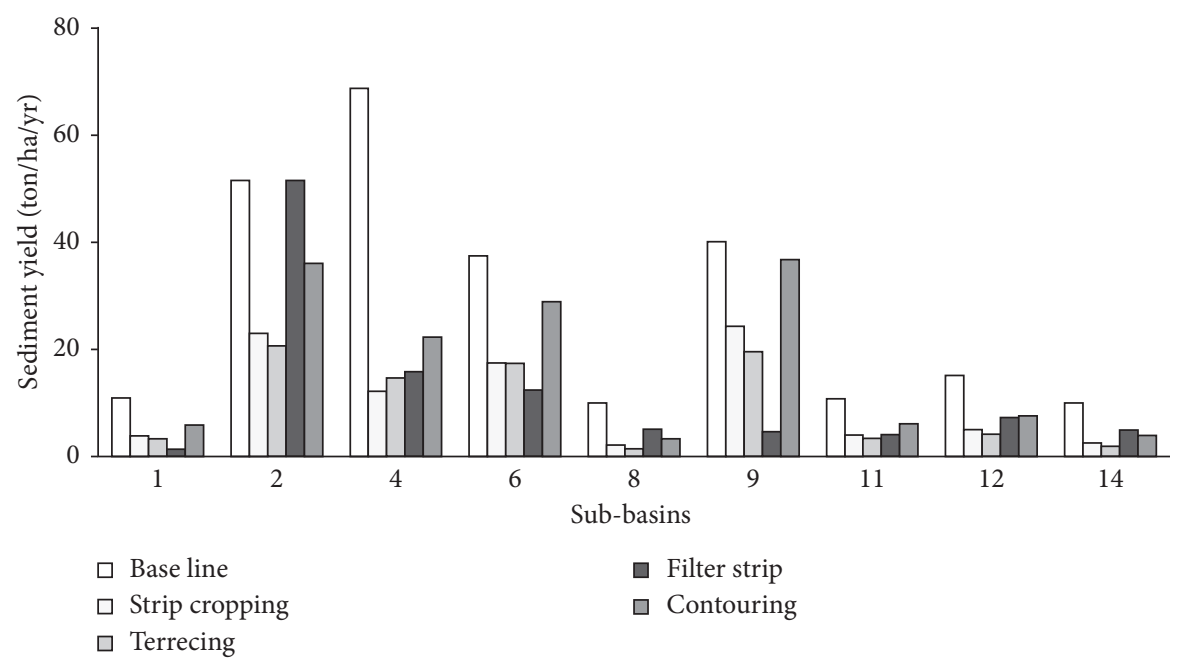

FIGURE 4: The average sediment yield from highly eroded subbasins without and with interventions.

watershed management of the area, four watershed management operations termed as scenarios were established and compared against baseline known as existing scenario. These scenarios were scenario I (contouring), scenario II (filter strip), scenario III (terracing), and scenario IV (strip contouring). Baseline scenario was used as a reference for comparisons of the effectiveness of the developed sediment reduction scenarios. In the baseline scenario, nine critical sediment source subbasins were identified that need watershed management to decrease the sediment loss from subbasins. Out of the nine hotspot subbasins, four were very high, one was high, and four were found moderate affecting the subwatersheds. The average sediment loss from the nine identified critical sediment source subbasins was 28.22 ton/ $\mathrm{ha} / \mathrm{y}$. The mean annual sediment yield from the nine subbasins was reduced by $40.79 \%$ with the maximum reduction at subbasin 4 after applying contouring. This indicates that the total sediment flow from these subbasins may reduce by $196.6 \mathrm{ton} / \mathrm{y}$ (346.96-150.4 ton/y) with an overall reduction of
$32.83 \%$. According to Czapar et al. [28], effective contouring is expected to reduce soil erosion by $50 \%$ of average annual sediment yield for the treated subbasins, and accordingly, the results obtained more or less comply the statement. $10 \mathrm{~m}$ width filter strips for the nine sediment susceptible to subbasins were applied in order to slightly minimize the average annual sediment yield decreasing from 28.22 ton/ha/ y to 11.87 ton/ha/y, which accounts for $57.97 \%$ reduction with a total reduction of $29.89 \%$ of the sediment yield on the whole [29]. Terracing practice used as part of the watershed management system represented to reduce the impact of erosion and yield of sediments in the watershed by reducing slope length and steepness of subbasins. Simulation of terracing on the selected critical sediment source subbasins by adjusting the USLE crop practice (TERR_P), curve number (TERR_CN), and slope length (TERR_SL) significantly reduced average annual sediment yield rate by $66.02 \%$ (28.22-9.59 ton/ha/y). Throughout the level of watershed, the mean yearly sediment output was summarized from 


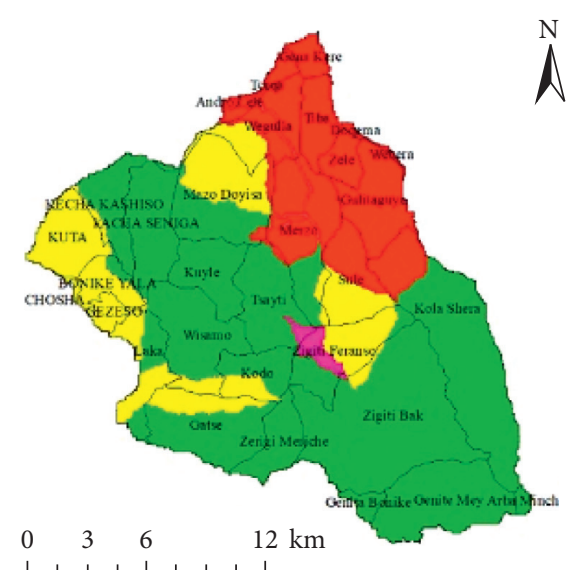

Baseline scenario (Existing)

Sed_yeild reate (ton/ha/yr)

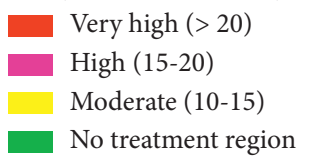

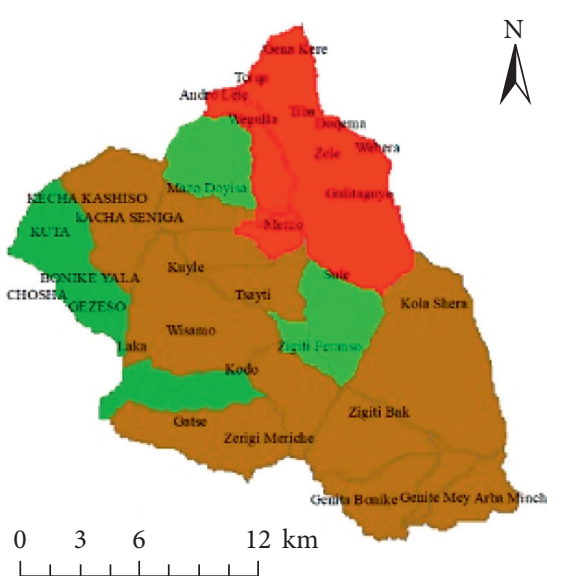

Contouring

Sed_yeild reate (ton/ha/yr)

Very high $(>20)$

Low $(5-10)$

Very low $(<5)$

No treatment region

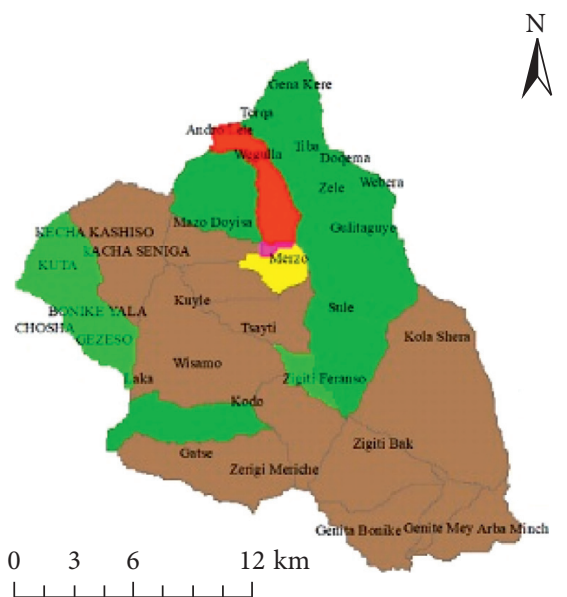

Filter strip

Sed_yeild reate (ton/ha/yr)

Very high $(>20)$

High (15-20)

Moderate (10-15)

Low (5-10)

Very low $(<5)$

No treatment region

(b)

(c) (a)

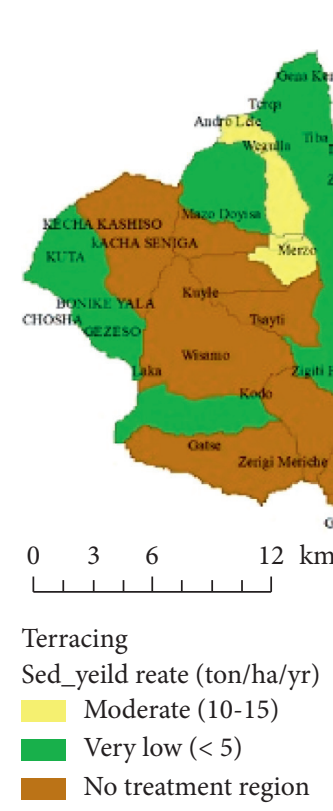

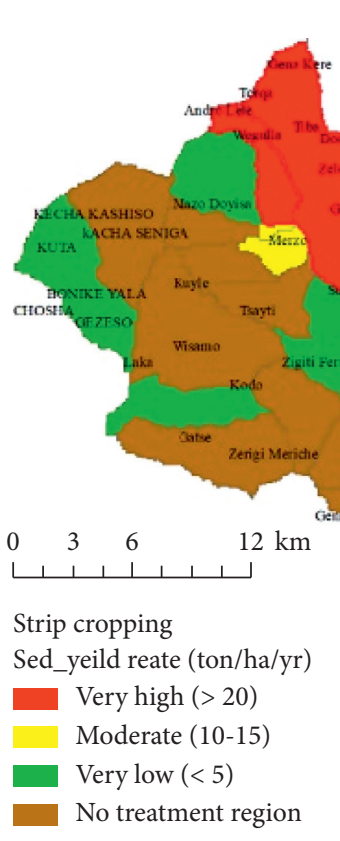

(e)

FiguRE 5: Spatial distribution of Kulfo watershed and kebeles overlaid before and after application of different interventions.

11.91 ton/y to 4.96 ton/y which accounts $58.35 \%$ sediment yield reduction [30].

When the slope and slope length are reduced by applying strip cropping, the peak runoff rate and erosive power of runoff are reduced harmoniously. Applying strip cropping on the nine sediment prone subbasins, it shows the mean annual sediment yield decreasing by $62.93 \%$; whereas, in the entire watershed level, the reduction was recorded as $53.74 \%$ of the sediment yields (Figure 4).
3.2.2. Comparison of Scenarios Result. As compared to the baseline scenario, all the selected interventions had shown significant reduction in sediment yield from all the subbasins. At the subbasin level, terracing was found to be the best intervention technique for subbasins $2,8,11,12$, and 14; whereas, filter strip was found reasonably better for subbasins 1 and 9. Application of filter strip at subbasin 2 negatively affects the subbasin and hence discarded. 
TABLE 4: Outline of scenarios compared with baseline scenario.

\begin{tabular}{|c|c|c|c|c|c|}
\hline \multirow[t]{2}{*}{ Scenario } & \multicolumn{2}{|c|}{$\begin{array}{l}\text { Mean sediment yield reduction annually at } \\
\text { hotspot subbasins }\end{array}$} & \multicolumn{2}{|c|}{$\begin{array}{l}\text { Mean sediment yield reduction annually in the } \\
\text { whole watershed }\end{array}$} & \multirow[t]{2}{*}{ Ranl } \\
\hline & Sediment reduction (ton/ha/y) & $\%$ reduction & Sediment reduction (ton $/ \mathrm{ha} / \mathrm{y}$ ) & $\%$ reduction & \\
\hline Baseline & 28.22 & - & 11.91 & - & \\
\hline Contouring & 16.71 & 40.79 & 8 & 32.83 & 4 \\
\hline Filter strip & 11.87 & 57.94 & 8.35 & 29.89 & 3 \\
\hline Terracing & 9.59 & 66.02 & 4.96 & 58.35 & 1 \\
\hline Strip cropping & 10.46 & 62.93 & 5.51 & 53.74 & 2 \\
\hline
\end{tabular}

The highest percentage reduction observed at the subbasin level was $88.4 \%$ (filter strip) at subbasin 9 and the minimum $8.3 \%$ (contouring) at the same subbasin. Figure 5 shows the reduction percentage in mean annual yield of sediments at the critical subbasins levels after applying different interventions (Table 4).

\section{Conclusions and Recommendations}

The developed intervention scenarios result revealed that mean sediment loss reduction in the whole basin at postapplication of contouring, filter strip, terracing, and strip cropping were $32.83 \%, 29.89 \%, 58.35 \%$, and $53.74 \%$, respectively. Twenty-one subbasins were created, and the average observed sediment yield was estimated to be 11.9 ton/ha/y. At treated subbasins level, once applying contouring, filter strip, terracing, and strip cropping, the mean annual sediment loss reduction was calculated as $40.79 \%, 57.94 \%, 66.02 \%$, and $62.93 \%$, respectively. The results depict that terracing was comparatively more favorable in reducing sediment yield than the remaining watershed interventions selected. The maximum sediment yield reduction obtained from terracing at a critical watershed level was $66.02 \%$. However, its effectiveness varies from region to region at critical subbasins of the study watershed [31].

\section{Data Availability}

The data used to support the findings of this study are available from the corresponding author upon request.

\section{Conflicts of Interest}

The authors declare that they have no conflicts of interest.

\section{References}

[1] D. M. Spalevic and C. Vukelic-Sutoska, "Soil erosion intensity and runoff on the djuricka river basin (north of Montenegro)," Malaysian Journal of Soil Science, vol. 17, no. 1, pp. 49-68, 2013.

[2] R. Kumar and U. Parven, "Integrated approach of universal soil loss equation (USLE) and geographical information system (GIS) for soil loss risk assessment in upper south koel basin, Jharkhand," Journal of Geographic Information System, vol. 04, no. 06, pp. 588-596, 2012.

[3] A. H. Sheikh, S. Palria, and A. Alam, "Integration of gis and universal soil loss equation (usle) for soil loss estimation in a Himalayan Watershed," Recent Research in Science and Technology, vol. 3, no. 3, pp. 51-57, 2011.
[4] V. Hrissanthou, P. Delimani, and G. Xeidakis, "Estimate of sediment inflow into vistonis lake, Greece," International Journal of Sediment Research, vol. 25, no. 2, pp. 161-174, 2010.

[5] I. Farhad, A. Jahangirzadeh, H. Basser et al., "Reservoir sedimentation based on uncertainty analysis," Abstract and Applied Analysis, vol. 2014, Article ID 367627, 6 pages, 2014.

[6] A. Tilahun, H. A. Shishaye, and B. Gebremariam, "Sediment inflow estimation and mapping its spatial distribution at subbasin scale: the case of Tendaho Dam, Afar Regional State, Ethiopia," Ethiopian Journal of Environmental Studies and Management, vol. 10, no. 3, pp. 315-339, 2017.

[7] N. Junakova and M. Balintova, "Predicting of soil loss in the tisovec catchment, Slovakia," AIDIC, vol. 28, pp. 265-270, 2012.

[8] V. Joshi, N. Susware, and D. Sinha, "Estimating soil loss from a watershed in western deccan, India, using revised universal soil loss equation," Landscape \& Environment, vol. 10, no. 1, pp. 13-25, 2016.

[9] S. J. Gale and R. J. Haworth, "Catchment-wide soil loss from pre-agricultural times to the present: transport- and supplylimitation of erosion," Geomorphology, vol. 68, no. 3-4, pp. 314-333, 2005.

[10] S. Angima, O. O'neill, and Weesie, "Soil erosion prediction using RUSLE for central Kenyan highland conditions," Journal of Agriculture, Ecosystems and Environment (Elsevier), vol. 97, pp. 295-308, 2002.

[11] C. Nyamekye, M. Thiel, S. Schönbrodt-Stitt, B. Zoungrana, and L. Amekudzi, "Soil and water conservation in Burkina Faso, west Africa," Sustainability, vol. 10, no. 9, p. 3182, 2018.

[12] F. Laekemariam, K. Kibret, T. Mamo, E. Karltun, and H. Gebrekidan, "Physiographic characteristics of agricultural lands and farmers' soil fertility management practices in Wolaita zone, Southern Ethiopia," Environmental Systems Research, vol. 5, no. 1, p. 24, 2016.

[13] M. B. Machmuller, M. G. Kramer, T. K. Cyle, N. Hill, D. Hancock, and A. Thompson, "Emerging land use practices rapidly increase soil organic matter," Nature Communications, vol. 6, no. 1, p. 6995, 2015.

[14] Fao, "Status of the world's soil resources: regional assessment of soil changes in Africa South of the Sahara," Food and Agricultural Organization of the United Nations, Rome, Italy, http://www.fao.org/3/a-bc598e.pdf, 2015.

[15] D. Moriasi, J. Arnold, M. Van Liew, R. Bingner, R. Harmel, and T. Veith, "Model evaluation guidelines for systematic quantification of accuracy in watershed simulations," Transactions of the ASABE, vol. 50, no. 3, pp. 885-900, 2007.

[16] L. Tamene, Z. Adimassu, E. Aynekulu, and T. Yaekob, "Estimating landscape susceptibility to soil erosion using a GISbased approach in Northern Ethiopia," International Soil and Water Conservation Research, vol. 5, no. 3, pp. 221-230, 2017.

[17] B. Bekele, A. Muluneh, and N. Wondrade, "GIS based soil loss estimation using universal soil loss equation model (USLE) 
for soil conservation planning in karesa watershed, dawuro zone, south west Ethiopia," International Journal of Water Resources and Environmental Engineering, vol. 11, no. 8, pp. 143-158, 2019.

[18] H. J. Kruger, F. Berhanu, and M. Y. Gebere, Inventory of Indigenous Soil and Water Conservation Measures on Selected Sites in Ethiopian Highlands Soil Conservation Research Report 34 Bern, Centre for Development and Environment (CDE), University of Bern, Switzerland, 1996.

[19] H. Hurni, "Soil erosion and soil formation in agricultural ecosystems: Ethiopia and northern Thailand," Mountain Research and Development, vol. 3, no. 2, pp. 131-142, 1983.

[20] A. Shiferaw, "Estimating soil loss rates for soil conservation planning in borena woreda of south wollo highlands of Ethiopia: the case from the legemara watershed," EJBE, vol. 1, no. 1, pp. 1-34, 2011.

[21] N. D. Melaku, C. S. Renschler, H. Holzmann et al., "Prediction of soil and water conservation structure impacts on runoff and erosion processes using SWAT model in the northern Ethiopian highlands," Journal of Soils and Sediments, vol. 18, no. 4, pp. 1743-1755, 2017.

[22] H. Hurni, K. Herweg, B. Portner, and H. Liniger, Soil Erosion and Conservation in Global Agriculture, , Springer, Dordrecht, 2008pp. 41-71, Land Use and Soil Resources.

[23] G. Ramteke, R. Singh, and C. Chatterjee, "Assessing impacts of conservation measures on watershed hydrology using MIKE SHE model in the face of climate change," Water Resources Management, vol. 34, no. 13, pp. 4233-4252, 2020.

[24] M. Talebizadeh, D. Moriasi, P. Gowda et al., "Simultaneous calibration of evapotranspiration and crop yield in agronomic system modeling using the APEX model," Agricultural Water Management, vol. 208, pp. 299-306, 2018.

[25] Abbaspour, User Manual for SWAT-CUP, SWAT Calibration and Uncertainty Analysis Programs, Swiss Federal Institute of Aquatic Science and Technology, Duebendorf, Switzerland, 2014.

[26] A. B. Asnake, M. T. Ayana, and A. A. Awass, "Transformation of climate and its sway on hydro-climatology using representative concentration pathways (RCP) in Geba catchment of Ethiopia," Model. Earth Syst. Environ, vol. 7, no. 1, pp. 2439-2451, 2020.

[27] J. Nash and J. Sutcliffe, "River Flow Forecasting through conceptual model: Part-A discussion of principles," Journal of Hydrology, vol. 10, no. 1, pp. 282-290, 1970.

[28] F. Czapar George, J. M. Laflen, G. F. McIsaac, and D. P. McKenna, Effects of Erosion Control Practices on $\mathrm{Nu}$ trient Loss, American Society of Agricultural and Biological Engineers, St. Joseph, MI, USA, 2005.

[29] Andualem and Gebremariam, "Impact of land use land cover change on stream flow and sediment yield. A case study of gilgel abay watershed lake tana sub basin Ethiopia," Int. J. of Tech. Enhancements and Emerging Eng. Res.vol. 3, no. 11, 2015.

[30] H. M. Mwangi, S. Julich, S. D. Patil, M. A. Patil, and M. A. Feger, "Modelling the impact of agroforestry on hydrology of mara river basin in east Africa," Hydrological Processes, vol. 30, no. 18, pp. 3139-3155, 2016.

[31] Van, "Model use, calibration and validation," American Society of Agricultural and Biological Engineers, vol. 55, no. 4, pp. 1491-1508, 2005. 